себе - тоді картина набула би іншого змісту. Осмьоркін таким чином вказує на прагнення закритись у внутрішньому просторі, не впускати в нього чужих, можливо, знайти вихід із складної ситуації, в якій він опинився в цей період життя. I тут певну роль відіграє дзеркало, яке неодноразово з'являлося в натюрмортах. Відображення в дзеркалі - це як би інша реальність, своєрідна гра, яка здатна трансформувати зміст оповідання.

Таким чином, звернення Осмьоркіна до світу предметів і наділення їх символічними значеннями відображає полімодальність мислення митця. Розглядаючи місце і роль конкретних предметів у просторі картини, ми представляємо цілісну картину світу живописця, в якій немає випадкових образів, та розуміємо композиційні акценти в картинному просторі.

\title{
Література:
}

1. Злыднева Н. В. Визуальный нарратив: опыт мифопоэтического прочтения. Москва: Индрик, 2013. 360 с.

2. Осмеркин. Размышления об искусстве. Письма. Критика. Воспоминания современников. Москва: Советский художник, 1981. 400 с.

3. Хузина Т. Е. Предметный мир в советской живописи 1930-х гг.: семантический анализ. Атореф. дисс. ... канд. искусствов-я: 17.00.09. Санкт-Петербург, 2009. 24 с.

DOI https://doi.org/10.30525/978-9934-26-004-9-48

\section{КАЗИМИР МАЛЕВИЧ ЖІНОЧИЙ ТОРС № 1: ФОРМА І КОЛІР}

\author{
Коваленко С. Г. \\ аспірант кафедри мистецтвознавчої експертизи \\ Національної академії керівних кадрів культури і мистецттв \\ м. Київ, Україна
}

Творча особистість Казимира Малевича в історії образотворчого мистецтва $є$ уособленням митця-новатора, філософа, що сформувався як художник на зламі епох і пошуків нових шляхів у мистецтві, синтезу культур, соціально-економічних потрясінь. Як інші художники авангарду, митець вже не зображував пророків і революціонерів, а сам проголошував себе провісником і руйнівником у мистецтві. В умовах інтенсивної мутації культурного генотипу зросла роль творчої ініціативи, 
напруженого інтелектуального пошуку, винахідництва: епоха ніби змусила людину повернутися до суспільства іншою гранню.

Природно, що майже перед кожним самобутнім майстром поставала потреба подолати стереотипи в соціумі. Тому конфлікт «поета» й «черні», «творця» і «натовпу» - не тільки романтична легенда, але й вічно повторювана ситуація, в якій розігрується одна й та ж колізіяпротистояння особистості і натовпу.

У цьому «революційному» контексті можна розглядати відомі в літературі випади Малевича проти ворожого йому музейного мистецтва, «археології», «мадонн і венер», «жіночих стегон у місячному світлі». Хоча, саме «археологія», архаїка, народне мистецтво, відкриття на межі століть феномену трипільської культури стали підгрунтям для «гарячого материка» українського авангарду. К.Малевич бачив у класичному «неправильному» мистецтві загрозу для людства, цивілізації, шлях у безодню.

Це дає змогу зрозуміти i парадоксальність, i вмотивованість звернення К.Малевича до портретного жанру, зокрема, так званої «метафізичної фігури», у контексті якого розглядаємо його роботу «Жіночий торс №1: форма i колір», також порушивши проблему стилістичної еволюції образу. Із пояснення самого митця випливає, «що тільки через розвиток свідомості ми можемо побачити в собі людину, i тільки тоді лик їі віддзеркалиться в природі... У теперішній час такого обличчя не існує, оскільки воно, як людина, розпорошено, образ його ми можемо побачити через множину форм, з'єднавши їх переплетіння в одну концентрацію»(пер.наш).

В основу статті покладено дослідження(рукописи) відомих фахівців - Д.О. Горбачова та Ж-К.Маркаде Над експертизою картини «Жіночий торс №1» Д. Горбачов працював не один місяць й упевнився, що то справжній К.Малевич.

Повернення К.Малевича до іконописного образу після 1927 року насправді є синтезом, у якому безпредметність притаманна фігурам людей, що зображені в позі вічності. Сам митець зізнавався: «Через іконописне мистецтво я зрозумів емоційне мистецтво селян, котре любив i раніше, але не засвоїв усього того смислу, який відкрився після вивчення ікон»(пер.наш). «Жіночий торс № 1»є синтезом чотирьох головних елементів, що викликають жвавий інтерес до цього твору: іконність, народний примітивізм, алогізм, енергія кольору.

Формально «Жіночий торс № 1» можна розглянути як супрематизацію ікони. Він є прототипом цілої серії картин і рисунків між 1928 і 1932 роками. Відомими є твори, які безпосередньо виникли слідом за ним: полотно «Торс 1928-1929» (ДРМ), на звороті якого рукою К. Малевича написано: «№ 3. первообразование нового образа. проблема 
цвет и форма и содержание», а на звороті нашої картини «Жіночий торс № 1» рукою Малевича написано: «№ 1 женский торс цвет и форма». Відомим є ще інший «Жіночий торс 1928-1929», що також знаходиться в ДРМ (дерево, олія), на звороті якого тією ж рукою художника написано: «№ 4 женский торс - развитие мотива 1918 года».

У картині «Жіночий торс № 1» йдеться про наступний етап у творенні «нового образу»: жіночий лик має око й рот (немає прямого зображення носа), зате йому притаманний супрематичний іконний позачасовий характер образу.

Саме в картині «Жіночий торс №1» ми бачимо, що три кольори сірий, чорний, червоний протистоять білому, використаному у фрагменті фігури та будинкові на його правій частині.

«Жіночий торс № 1» дозволяе глянути i переосмислити постсупрематичну творчість, до цього часу описану хаотичнонесистемно, у приблизному порядку, найчастіше за тематичним принципом.

Картина «Жіночий торс № 1», очевидно, є прототипом цілої групи творів 1928-1929 років, коли український живописець продовжив досліджувати можливості представити новий образ людини на лоні «нареченої-землі» через відчуття безпредметного світу. Йдеться про нове втілення супрематизму в іконних контурах.

Примітивізм. Обличчя в картині «Жіночий торс № 1» не має конкретних рис (прадавній знак табу), а помережане знаком ритуального хреста, що робить його та інших персонажів картин Малевича прямими нащадками українських народних ляльок-мотанок.

Спектралізм К.Малевича в його роботі «Жіночий торс № 1 » $\epsilon$ напруженим, драматичним.

Малярські переживання - це зв'язок художника 3 космосом через його почуття. У «Жіночому торсі № 1» відчуття безкінечності витворено білим кольором. Біле, а не синє дає це відчуття, стверджував художник. Білостінний будинок на картині викликає асоціації з білим тлом хати, на якому юний Казимир разом із селянками робив орнаментальні розписи 3 чітким ритмом, пластичними паузами.

Пейзаж у картині «Жіночий торс № 1»- це барвисті смуги, подібні до лінійних чергувань подільських ряден. Як відомо зі спогадів митця, він кілька юних років жив на Поділлі, і враження дитинства відклалися у свідомості Казимира як фотонегативи, щоб «проявитися» в зрілому віці як позитиви.

Актуальність цього дослідження полягає в тому, що серію картин «Жіночий торс» доповнено роботою, що увійшла до наукового контексту у світлі образотворчих та наукових пошуків К. Малевича, висвітлених у науковій праці «Аналіз нового та образотворчого мистецтва» (1928), де 188 
художник філософськи осмислює сутність авторської стилістики напрямку супрематизму.

Сюжетна сдність картин «Жіночий торс № 1 - № 4» досліджуваної серії поступається місцем кольоро-конструктивній, де Малевич показує себе неперевершеним майстром гранично стиснутих, наповнених великою силою сугестії, лапідарних живописно-пластичних формулювань. Це передбачає витончене відчуття цілісності картини. Проект цілісної побудови в цьому випадку, безумовно, є початковим та визначальним. Знову ж таки, тут можна привести смислові паралелі 3 давньоруським живописом, говорячи про значення в ній «соборного плану», «підпорядкування живопису архітектурі». Саме це конструктивно-архітектурне начало виявилось більш зрозумілим для творчої свідомості Малевича, де втілено підкорення людини ідеї собору, перевага вселенського над індивідуальним. Тут людина перестає бути самодостатньою особистістю і підкорюється загальній архітектурі цілого.

Генетичну закоріненість Казимира Малевича в український світ - від селянського побуту до народного мистецтва підкреслено роботами Д. Горбачова, О. Найдена та інших.

В особистості Малевича - етнічній, людській, мистецькій, поєдналось багато - польсько-українська кров, вітчизна і західна культура.

В його творчості помітно спробу з'єднати цілісні категорії вітчизняної культури i культури європейської, що бере початок зі спадщини Ренесансу. Головне в ній - уявлення про особистість як про монаду, протиставлення іiі світу. Ця «опозиція» повинна вирішитись завдяки здатності людини бути - на основі досягнень технічного прогресу - деміургом світу. Але в реальності все виявляється не так просто... Відповідаючи потребам сучасної цивілізації, мистецтво Малевича являє образи, які можна вважати проектами або «передчуттями» нової дійсності.

«Західна орієнтація» Малевича є своєрідною, позначеною також своїм світовідчуттям: ідеї технічного прогресу він сприймає 3 національним максималізмом, про що свідчить вже згадуваний «український слід» в його мистецтві.

Сувору раціоналістичність своїх композицій він «підправляє» алогізмом: вписуючи в абстрактно-геометричні форми, що їх диктувала техногенна цивілізація, фігури селянок, бачить в них і контури майбутніх роботів, і обриси кам'яних баб; створюючи всі передумови для естетики індустріального дизайну,

Його «українська душа» відкидає суто утилітарний зміст супрематизму, наголошуючи і на його ідеально-філософській сутності. 
Пошуки загальних основ у суто індивідуальній творчості спирались на «першоелементи» мови живопису, пряму і серповидну лінії в кубізмі, «кристали» квадрата і круга в супрематизмі і т.п. На основі «обростання» цих першоелементів емоційно-асоціативними значеннями живопис починає оперувати варіаціями «чистої» пластичної форми, що можна бачити у досліджуваній роботі «Жіночий торс № 1» та інших творах 3 цієї серії.

Для дослідження було проаналізовано і використано хіміколабораторний, подчеркознавчий (графологічна експертиза підпису), мистецтвознавчий аналізи. Це дало точну оцінку творчого стану i напрямку образно-стилістичної думки К. Малевича - народження форми і кольору в образі жіночого торсу. Ці дослідження змогли прослідкувати нумерацію серії картин «ЖІНОЧИЙ ТОРС».

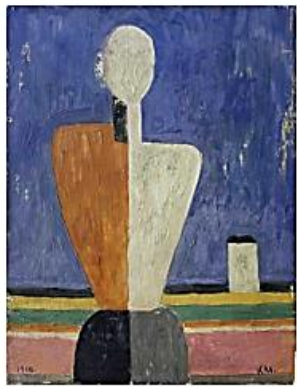

«Жіночий торс № 1»

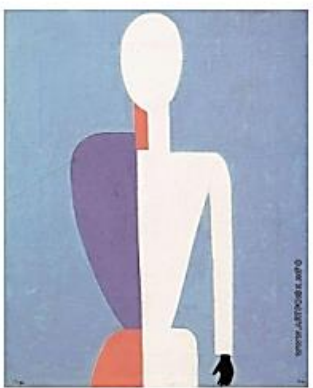

«Жіночий торс № 3»

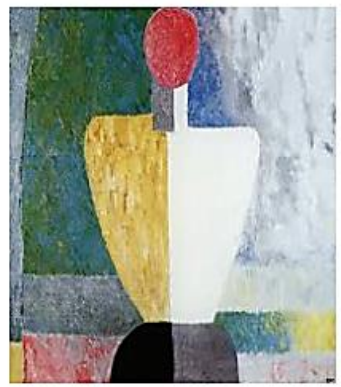

«Жіночий торс № 2»

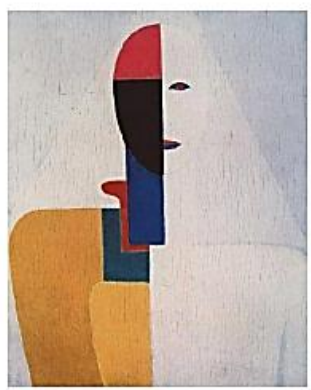

«Жіночий торс № 4»

На думку експерта - мистецтвознавця з Франції Жан-Клода Маркаде, на цей момент дослідження ми можемо спостерігати за роботами «Жіночий торс № 1, № 2, № 3, № 4». Цей результат наукових мистецтвознавчих досліджень дозволяє ствердити, що на сьогодні це 
одне $з$ найяскравіших і найглибших досліджень одного із творів киянина, авангардиста Казимира Малевича.

\section{Література:}

1. Горбачов Дмитро. Перший (Київський) «Жіночий торс» Малевича з серії «Форма і колір». Рукопис. С. 1-14.

2. Горбачов Д., Мельник В. Український авангард // Пам'ятки України - 1991- № 90.

3. Гренберг Ю., Писарева С. Масляные краски XX века и експертиза произведений живописи. Планета Музыки. Москва. 2017.

4. Казимир Северинович Малевич «Форма, колір і відчуття». «Сучасна архітектура», 1928, № 5, С. 157-159.

5. К.С. Малевич, «Архітектура, станковий живопис, скульптура» [1929], в кн. Казимир Малевич. Київський период 1928-1930 (склала Тетьяна Філевська), Київ, Родовід, 2016, с. 127.

6. Малевич К. З автобіографії // Україна. - 1988. - № 29.

7. Малевич К. Архітектура, станкове малярство та скульптура // Авангард-альманах пролетарських митців «Нова генерація» - К., 1930. - № B.

8. Методика дослідження рукописних записів і підписів, виконаних на незвичному матеріалі письма незвичними пишучими приладами (р/код 1.1.55). - Харків, 2012.

9. Маркаде Ж.-К. «Жіночий торс № 1» Малевича. Рукопис, с. 8-9.

10. «Нова генерація» (Харків, № 6-9,1930).

11. Судебно-почерковедческая експертиза. - М., 1971. - ч. 1, 2.

DOI https://doi.org/10.30525/978-9934-26-004-9-49

\section{ТЕНДЕНЦІЇ РОЗВИТКУ СУЧАСНОЇ УКРАЇНСЬКОЇ КЕРАМІКИ}

\section{Кулініч Л. О.}

стариий викладач кафедри образотворчого мистецттва та дизайну Центральноукраїнського державного педагогічного університету імені Володимира Винниченка м. Кропивницький, Україна

Сучасна художня кераміка - яскраве явище в українському мистецтві. Поява і становлення професійної художньої кераміки пов'язане 3 процесами, що відбувалися в культурно-мистецькому середовищі другої половини XX століття. До середини XX століття завданням професійної кераміки вважалося вивчення і інтерпретація надбань традиційного 